\author{
Jacek PIELECHA ${ }^{1}$ \\ Remigiusz JASIŃSKI ${ }^{2}$ \\ Jarosław MARKOWSKI ${ }^{3}$
}

\title{
THE EMISSIVITY OF THE TURBINE ENGINE POWERED BY BIOFUEL
}

\begin{abstract}
Air transport is the youngest and most dynamically developing branch of transport. Growth in demand for air transport, both passenger and freight, is caused by the competitiveness of this branch primarily in terms of time and transport safety. An increase in the volume of air traffic is associated with increased emissions, which is particularly important in the case of aircraft operations in the areas of airports. The main reason for the development of aircraft engines is the reduction of fuel consumption and exhaust emissions. Emission standards for aircraft engines certification marginally treat the issue of particulate matter emissions, which is associated with deterioration of visibility appearing as smog and contributes to lung and heart diseases. One of the solutions for limiting the negative impact of the aircraft on the environment is the use of alternative fuels. Production of biofuels in accordance with the principles of sustainable development, is an attractive alternative, especially because of the lack of space constraints of their production allows the geographical diversification of supply. The article presents the measurements results of jet engine GTM-120 exhaust emissions. The test engine was powered with Jet A-1 fuel with 50-percent addition of bioester. During the test concentration of carbon monoxide, hydrocarbons and particulate matter was measured. On the basis of the measurements, the effect of the use of biofuel on emissions was presented.
\end{abstract}

Keywords: biofuels, jet engine, emissions, air transport

\section{Introduction}

The development of air transport contributes to the increase in the number of conducted flight operations, resulting in the need to increase the number of operated aircraft. The result of the dynamic development of air transport is the increasing demand for fossil fuels that generates increased emissions of harmful exhaust compounds. Emissions from air transport adversely affect air quality,

\footnotetext{
1 Autor do korespondencji/corresponding author: Jacek Pielecha, Politechnika Poznańska, ul. Piotrowo 3, 60-965 Poznań, tel. 61-6652118, e-mail: jacek.pielecha@put.poznan.pl

${ }^{2}$ Remigiusz Jasiński, Politechnika Poznańska, e-mail: remigiusz.w.jasinski@doctorate.put.pl

${ }^{3}$ Jarosław Markowski, Politechnika Poznańska, e-mail: jaroslaw.markowski@put.poznan.pl
} 
particularly in the vicinity of the airports; it also contributes to the greenhouse effect. The topic of emissions from combustion engines has gained a lot of interest in the scientific community [1] and involved public opinion [9] due to the known association between exposure to multiple air pollutants and short and long-term effects on human health [16]. In addition, pollution from engines can cause deterioration of visibility [4] and directly or indirectly affect the climate [14].

The growing knowledge of the processes involved in the creation of air pollution from combustion engines and a dynamic development of emission measuring devices lead to the creation of new rules and conditions for the certification of aircraft engines [12]. The first emission standards for aircraft engines were introduced in the late $70 \mathrm{~s}$, of the twentieth century, by the International Civil Aviation Organization (ICAO). Key provisions in the framework of measures to reduce the emissions of harmful compounds from aircraft engines have been introduced by ICAO in Volume II of Annex 16 to the Convention on International Civil Aviation (i.e. The Chicago Convention) [5]. The aforementioned document includes recommendations on the measurement methods of carbon monoxide (CO), nitrogen oxides (NOx), hydrocarbons (HC) and smoke number (SN) [6].

The existing situation contributes to stricter requirements for the environmental performance of aircraft engines [15]. One of the ways of meeting the environmental protection requirements for aircraft engines is the introduction of alternative fuels intended for use in aircraft engines. The most common alternative fuels are ethanol, and esters of vegetable origin. Alternative fuels classed for use in air transport must meet strict criteria, including physicochemical properties directly affecting the combustion process, costs of production, availability, impact on the environment in addition to meeting all the safety requirements [2].

The popularity of natural sources of energy based on biomass is the result of limited oil resources. In addition, an increase in global energy demand and interest in the issue of restricting the emissions of harmful exhaust components, promote the development of these kinds of energy sources. Currently, the share of biofuels in comparison with traditional fuels is small, but in the long run, the importance of biofuels and other unconventional energy sources will increase [3]. The use of unconventional energy sources can help to reduce oil consumption [13], and in particular help to balance the proportion between the types of fuels used in transport [8], which is currently dominated by petroleum products [10]. The development of the biofuel market is heavily dependent on the state of oil prices, the spread of new generations of biofuels, as well as the development of alternative energy sources (e.g. wind and solar) that could be implemented in the transport sector. The particular importance for the development of the biofuel market are also prospects for the use of biofuels in civil and military aviation. There is a noticeable increase in interest in biofuels for use in aviation. In con- 
nection with the assessment of the possibilities of using biofuels to power turbine engines, a number of laboratory tests have been carried out and test flights using this type of fuel have been conducted. Despite the prevalence of traditional aviation fuels, caused by their operational characteristics, conducted research focuses on the use of plant products to be used as additives to conventional fuels. Research work is being undertaken by leading airline companies (Boeing, Airbus), that are supporting the development of alternative fuels and arrange test flights for aircraft powered with biofuels.

One of the international initiatives supporting the development of biofuels in aviation is the project called BIOJet Abu Dhabi, launched in 2013. The institutions and companies involved in the project include: Boeing, Etihad Airways, Takreer, Total, and Masdar Institute of Science and Technology. The initiative aims to promote the use of biofuels in the aviation sector in the UAE (United Arab Emirates) and focuses on research, development and investment in the production of raw materials and fuel refining capabilities [11].

Actions taken towards environmental protection, done through the use of bio-components in powering turbine engines, are a result of obliging the aviation sector to reduce carbon dioxide emissions and, starting in 2020, moving in line with the EU directive on the Emissions Trading System (ETS). In addition to verify the possibility of using biofuels in aviation, research includes developing new aviation biofuel technologies, based on the use of plants not used in the food and nutrition industry, such as: jatropha, camelina and microalgae.

\section{Method}

Studies on the effects of bioester admixture on the emission of harmful exhaust compounds were carried out using a GTM-120 jet engine installed on a stationary workbench (Fig. 1). The engine consists of a single-stage radial compressor which is connected to a single-stage axial turbine. The GTM-120 engine uses an annular combustion chamber and the fuel is supplied to the set of vaporizers [7]. Engine ignition is initiated using an electric starter, glow plugs and propane-butane gas, which is the engine power supply during this phase of operation. After reaching a certain speed of the motor shaft, the system automatically switches to the appropriate fuel supply. The workbench has an electronic engine control unit, whose task is to perform all the control functions including automatic start-up and cooling. Engine is controlled by adjusting the fuel pump flow. The engine workbench allows for registering and reading parameters such as: the motor shaft speed, temperature of the gases behind the turbine and the engine thrust. 


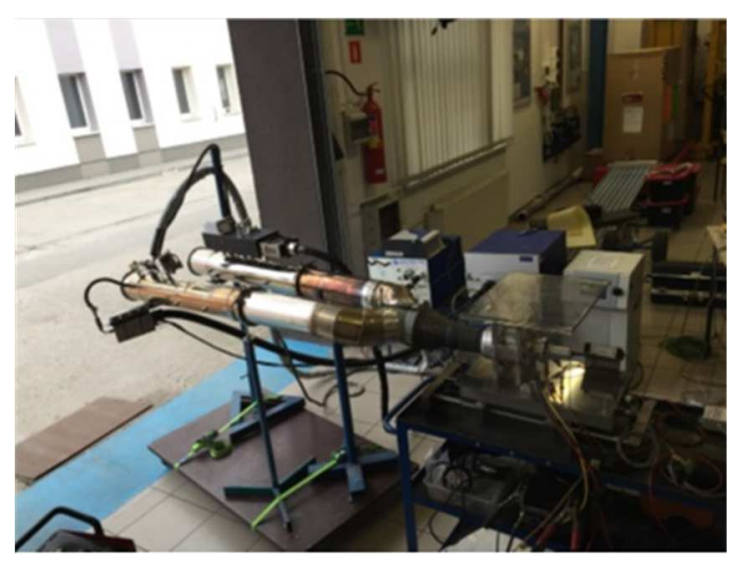

Fig. 1. Engine workbench view

Methyl ester of fatty acids of plant origin, used in this research as an additive to traditional fuel, is produced by catalytic esterification of fat present in vegetable oils with methanol. Such esters may be present in the form of a biocomponent as an additive to diesel fuel or independently as a fuel (biodiesel).

The use of methyl esters as biofuels requires meeting the physicochemical demands included in their specific regulations. Some of those parameters depend on the bioesters production technology, for others on the procedure followed for purification, for others still on the type of materials used. The basic raw materials for the preparation of bioesters include vegetable oils predominantly composed of fatty acids with 18 carbon atoms in the chain, and with varying degrees of unsaturation.

The main objective of the research was to assess the emission of harmful compounds in exhaust gases of a jet engine, powered with aviation fuel Jet A-1 with an additive of methyl ester (FAME). For testing the emissions of harmful exhaust compounds a proper gas analyzer was used in combination with an EFM (Exhaust Flow Meter) with a diameter of $125 \mathrm{~mm}$. Additionally, an EFMHS (High Speed Exhaust Flow Meter) flow meter was used, characterized by a sampling frequency of $2500 \mathrm{~Hz}$, at the same diameter. The application of two flow meters installed in parallel on the workbench enabled the measurement of the mass flow of exhaust from the tested jet engine. The schematic of the engine workbench is shown in Fig. 2.

Measurement of particle diameters was performed with a EEPS 3090 (engine exhaust particle sizer ${ }^{\mathrm{TM}}$ spectrometer) mass spectrometer. It enabled the measurement of a discrete range of particle diameters (from $5.6 \mathrm{~nm}$ to $560 \mathrm{~nm}$ ) on the basis of their differing speeds. The degree of electric mobility of particulate matter is changed exponentially, and measurement of their size is carried out at a frequency of $10 \mathrm{~Hz}$. 


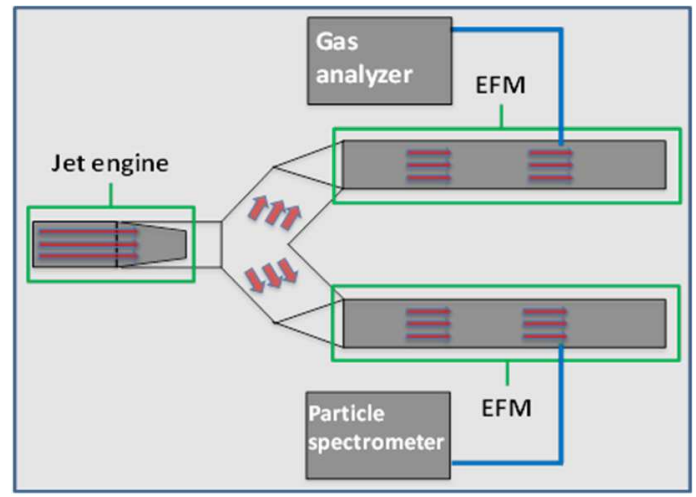

Fig. 2. Engine workbench schematic

Studies of exhaust emissions from the jet engine were performed with two types of fuel. The first test cycle was to perform measurements when engine is supplied with traditional aviation fuel Jet A-1. The results of emissions of harmful exhaust compounds when running on conventional jet fuel were the reference point for the second test cycle, in which the engine was fed a mixture of Jet A-1 with a 50-percent addition of FAME. Each test cycle consisted of measurements carried out with the engine operating parameters set to make it capable of producing thrust in the range between $10 \mathrm{~N}$ and $120 \mathrm{~N}$. In the case of particles size distribution, the measurements were carried out according to the level of engine load. Due to the high temperature of the exhaust gases from the tested jet engine the measuring equipment was positioned close to the engine with a specially made platform for the time of measurement, followed by a certain period of time when the sample of exhaust gases was collected. After completing measurements for one set of engine operating parameters the test stand was moved away and changes to the operating parameters of the engine were made.

\section{The results of measurements and its analysis}

Diameter distributions of particles emitted by the engine turbine GTM-120 were determined using an apparatus for measurement of particulate emissions from combustion engines. Figures 3-8 show measurement results for each of the level of engine load.

In the case of an engine powered by pure kerosene at minimum engine load (10\%) particles with diameters of $20-40 \mathrm{~nm}$ dominates (Fig. 3). The characteristic value of particle diameter distribution obtained from measurements was $30 \mathrm{~nm}$. There were no emissions of particles with diameters greater than $100 \mathrm{~nm}$. Measurement of particles concentration was performed for engine operating points corresponding to the percentage load. 


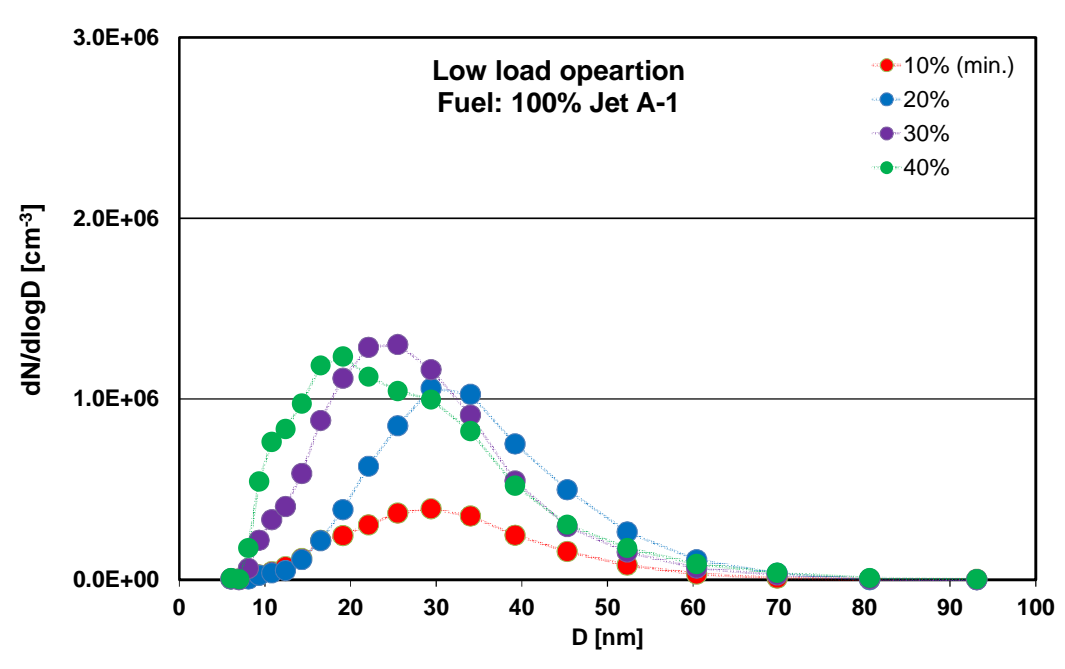

Fig. 3. Dimensional distribution of particles corresponding to low load operation (pure kerosene)

Diametrical distribution of particles emitted in the case of an engine supplied with biofuel admixture, is characterized by an increase in the diameter of the particulate matter in relation to the distribution obtained when the engine was fueled with clean Jet A-1 fuel (Fig. 4). Particle diameters between 20-50 $\mathrm{nm}$ were dominant, and the value of the characteristic diameter of the discussed diametrical distribution of particles was $35 \mathrm{~nm}$.

The obtained diametrical distributions of particulate matter for the engine fueled with Jet A-1 and operated at medium level of engine load (Fig. 5) was dominated by small particles with diameters of $20-40 \mathrm{~nm}$. The increase in engine load does not significantly affect dimensional distribution of emitted particles. It can be seen only the fluctuation in the concentration of particles depending on the engine load. There was no emission of particulates with diameters greater than $100 \mathrm{~nm}$. The addition of biofuel resulted in double reduction of the concentration of particles emitted (Fig. 6). For all engine load values in the range of medium loads, the concentration of particles emitted were pretty similar. There were no significant changes in the size distribution of particles. Particles with diameters of $20-40 \mathrm{~nm}$ were dominating. There were no emissions of particles with diameters greater than $100 \mathrm{~nm}$. 


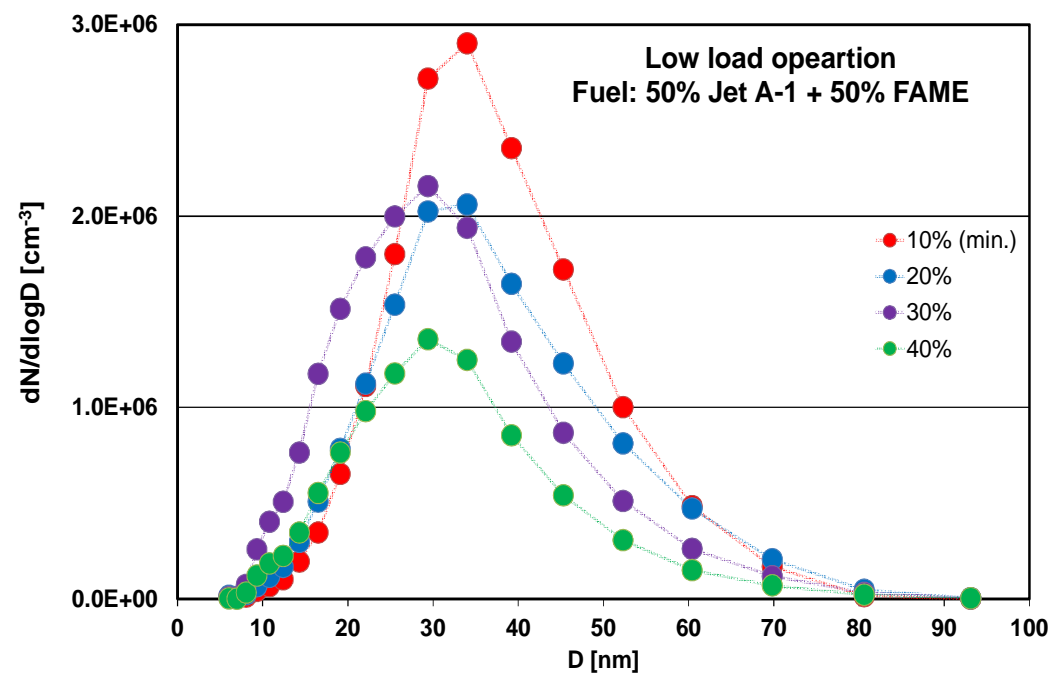

Fig. 4. Dimensional distribution of particles corresponding to low load operation (biofuel admixture)

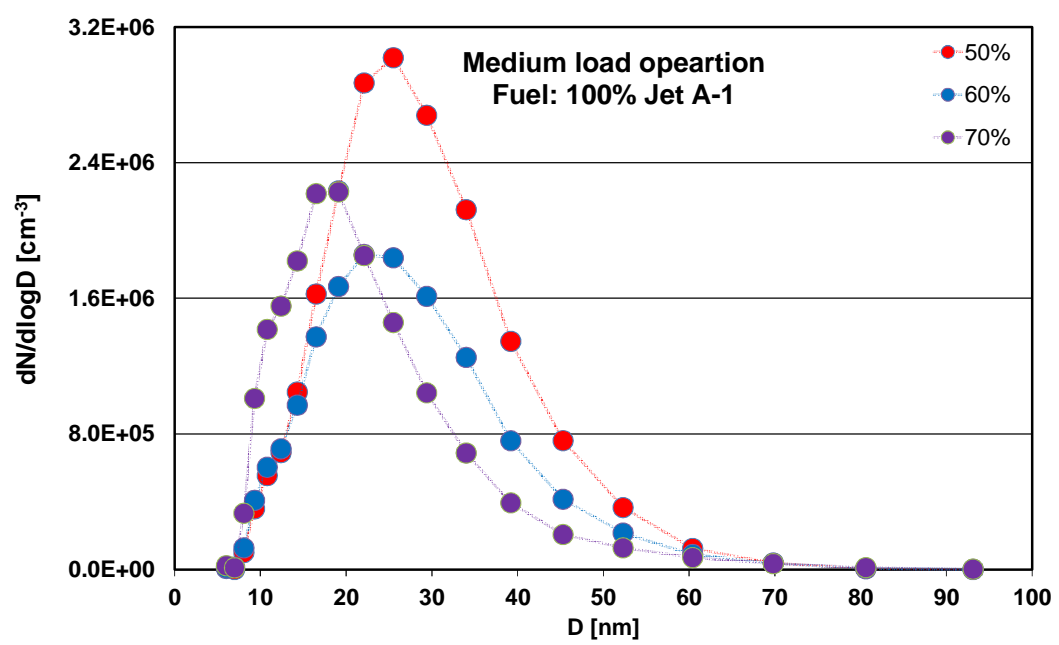

Fig. 5. Dimensional distribution of particles corresponding to medium load operation (pure kerosene) 


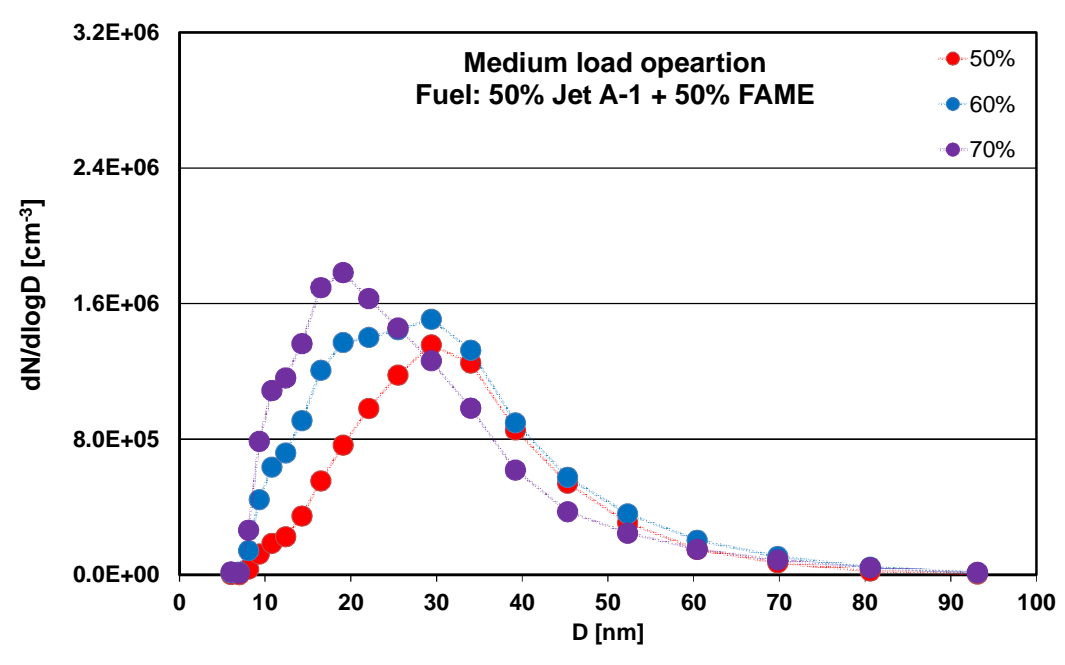

Fig. 6. Dimensional distribution of particles corresponding to medium load operation (biofuel admixture)

Increasing the level of engine load for the engine fueled with Jet A-1 to 80-100\% resulted in a reduction of the diameter of particles emitted (Fig. 7). Emissions were dominated by particles with the smallest diameters, from $20 \mathrm{~nm}$ to $30 \mathrm{~nm}$. The average diameter of emitted particles has been reduced, but also, the decrease in their scope was found. Particles emitted by the jet engine operating at full load were characterized by the diameter range of 10-20 nm. The concentration values over the range of high load values were similar.

In the case of using biofuel, there were no significant differences in both the concentration and size distribution of particles (Fig. 8). Particles in range 10-20 nm were dominant. In the case of maximum value of engine load the particles concentration was the highest and reached $3 \cdot 10^{6} \mathrm{~cm}^{-3}$. There were no emissions of particles with diameters greater than $100 \mathrm{~nm}$. Although the average value of the characteristic diameter of the obtained diametrical distribution was the same as in the case of Jet A-1 fuel $(20 \mathrm{~nm})$, there is a noticeable increase in the number of particulates having diameters greater than $20 \mathrm{~nm}$.

Using an apparatus for measuring the emissions of harmful exhaust compounds from combustion engines emissions per second of carbon monoxide and hydrocarbons were recorded for the engine fueled with Jet A-1 fuel, and a mixture of Jet A-1 and FAME in a 1:1 ratio. Based on the characteristics of the emissions of harmful compounds and a statistical analysis of the average emission of pollutants per second was determined for each measured value of thrust. In addition, in each case the emissions were determined in relation to the fuel consumption. 


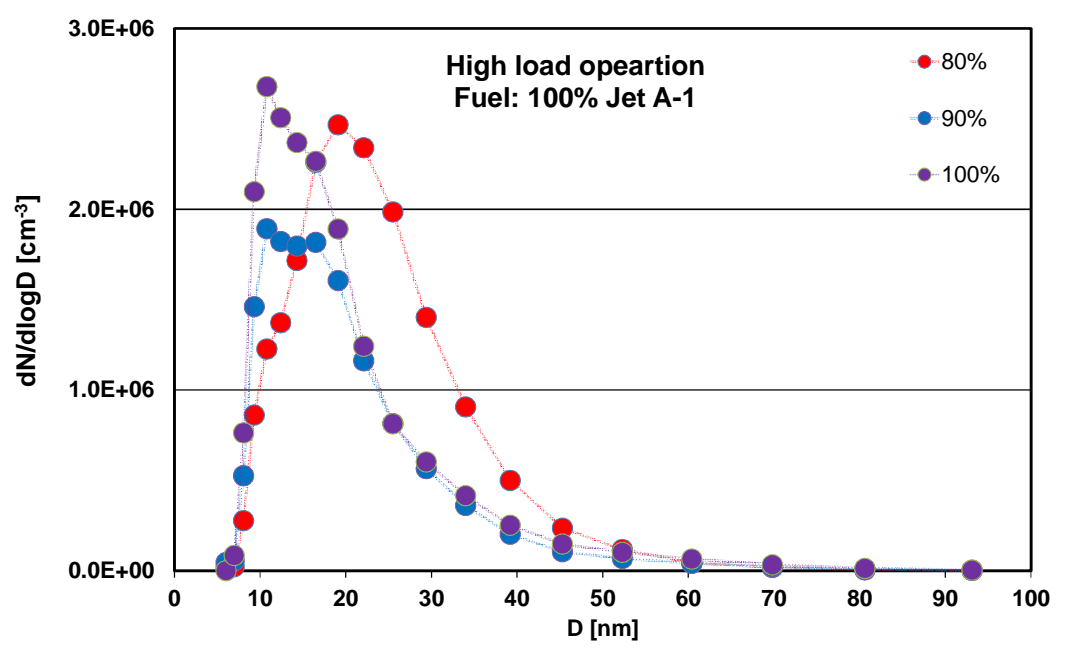

Fig. 7. Dimensional distribution of particles corresponding to high load operation (pure kerosene)

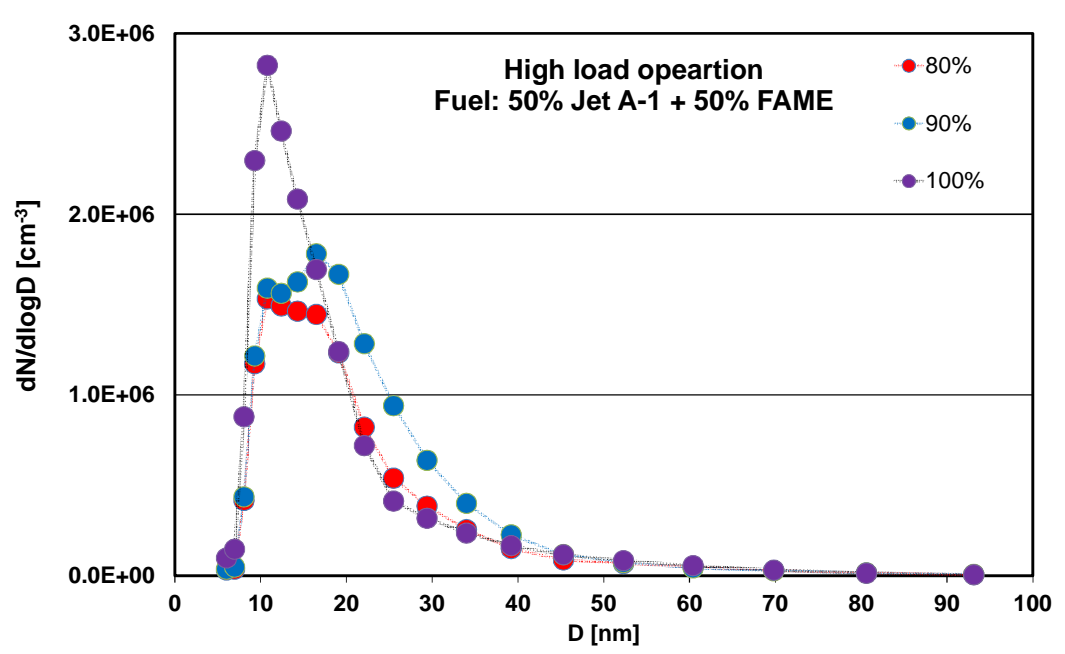

Fig. 8. Dimensional distribution of particles corresponding to high load operation (biofuel admixture)

In the case of an engine powered by pure kerosene in whole range of thrust an increase in the intensity of $\mathrm{HC}$ emissions was noticed. At the minimum value of thrust $(10 \mathrm{~N})$ the intensity of $\mathrm{HC}$ emissions was $50 \mathrm{mg} / \mathrm{s}$ (Fig. 9). Along with thrust increasing the intensity of hydrocarbon emissions was growing reaching $140 \mathrm{mg} / \mathrm{s}$ at a maximum value of thrust $(120 \mathrm{~N})$. The specific $\mathrm{HC}$ emissions (in relation to fuel consumption) along with thrust increasing showed a declining 
trend. During engine operation at the minimum value of thrust the specific $\mathrm{HC}$ emissions was $40 \mathrm{~g} / \mathrm{kg}$. In the entire range of thrust it decreased by $30 \%$ and reached $27 \mathrm{~g} / \mathrm{kg}$.

The most important result of the use of biofuels was a significant reduction in emissions of hydrocarbons (Fig. 10). The main trends of changes in emissions while loading the engine was consistent with measurements made for engine powered by pure Jet A-1. However, specific emission was significantly smaller. For maximum value of thrust reached $20 \mathrm{~g} / \mathrm{kg}$, about $25 \%$ less than in the case of pure kerosene.

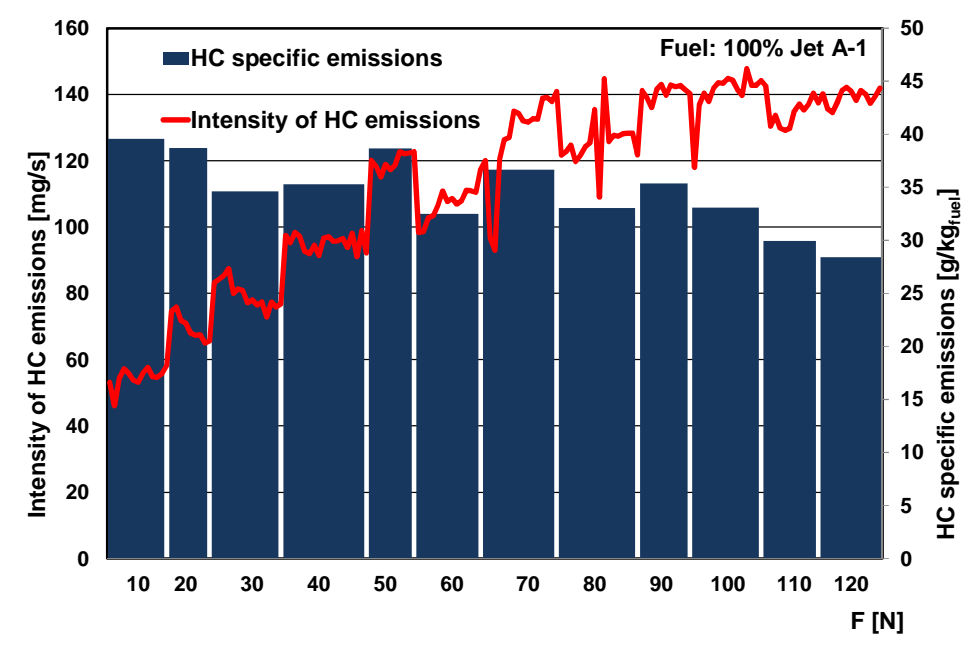

Fig. 9. The intensity of hydrocarbons emissions and the specific emissions for the jet engine powered with Jet A-1 fuel

In the case of an engine powered by pure kerosene in the range of small values of thrust an increase in the intensity of $\mathrm{CO}$ emissions was noticed. At the minimum value of thrust $(10 \mathrm{~N})$ the intensity of $\mathrm{CO}$ emissions was $130 \mathrm{mg} / \mathrm{s}$ (Fig. 11). Along with thrust increasing the intensity of $\mathrm{CO}$ emissions was growing reaching $350 \mathrm{mg} / \mathrm{s}$ at $50 \mathrm{~N}$ of thrust. In the course of further increasing the thrust value, the fluctuations of intensity of $\mathrm{CO}$ were observed. The specific $\mathrm{CO}$ emissions (in relation to fuel consumption) along with thrust increasing showed a declining trend in whole range of thrust. During engine operation at the minimum value of thrust the specific CO emissions was $140 \mathrm{~g} / \mathrm{kg}$. In the entire range of thrust it decreased by $50 \%$ and reached $70 \mathrm{~g} / \mathrm{kg}$ at maximum level of thrust. 


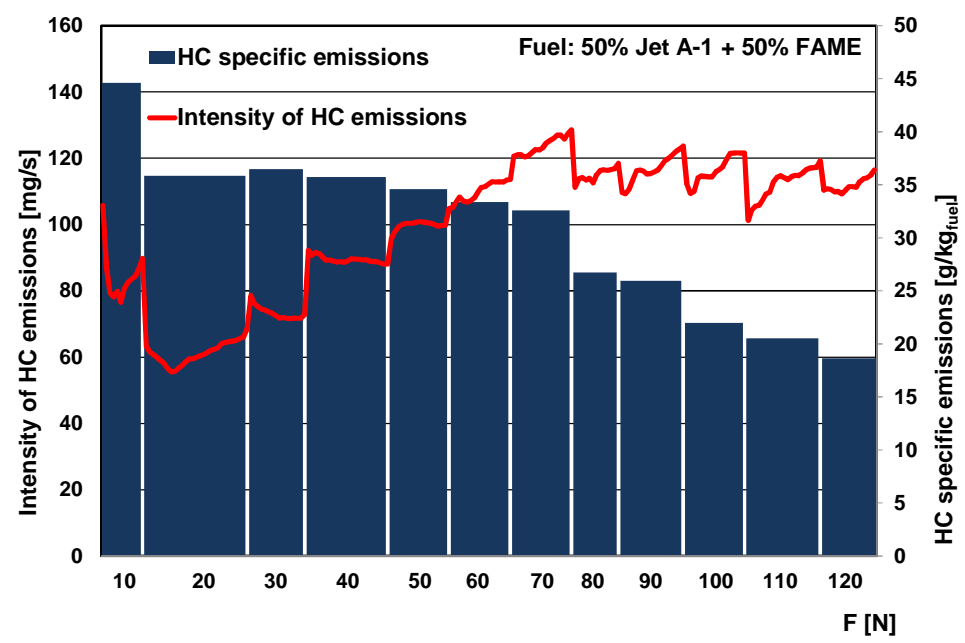

Fig. 10. The intensity of hydrocarbons emissions and the specific emissions for the jet engine powered with biofuel

In the case of engine powered by biofuel the main trends of changes in emissions while loading the engine was consistent with measurements made for engine powered by pure Jet A-1 (Fig. 12). In the range of small values of thrust an increase in intensity of $\mathrm{CO}$ emissions was observed. In the course of further increasing the thrust value, the fluctuations of intensity of $\mathrm{CO}$ were observed leading to $300 \mathrm{mg} / \mathrm{s}$ at maximum level of thrust. The specific emission was slightly smaller at maximum level of thrust in comparison to engine powered by pure kerosene and reached $50 \mathrm{~g} / \mathrm{kg}$.

\section{Conclusions}

In order to consider the effects of the addition of bioester to fuel on the intensity of the emissions of harmful exhaust compounds in aircraft engines, measurements of the emission intensity of carbon monoxide, hydrocarbons and particles were performed for the GTM-120 jet engine, powered with pure kerosene (Jet A-1) and its blend with bioester.

Overall, based on the measurements of particles emissions it can be stated that the use of biofuels has a negligible effect on their emissions. There has been a change in particle concentration, depending on the fuel used in individual ranges of engine load. These differences, however, are not so important to find a significant impact of biofuel on particles emissions. 


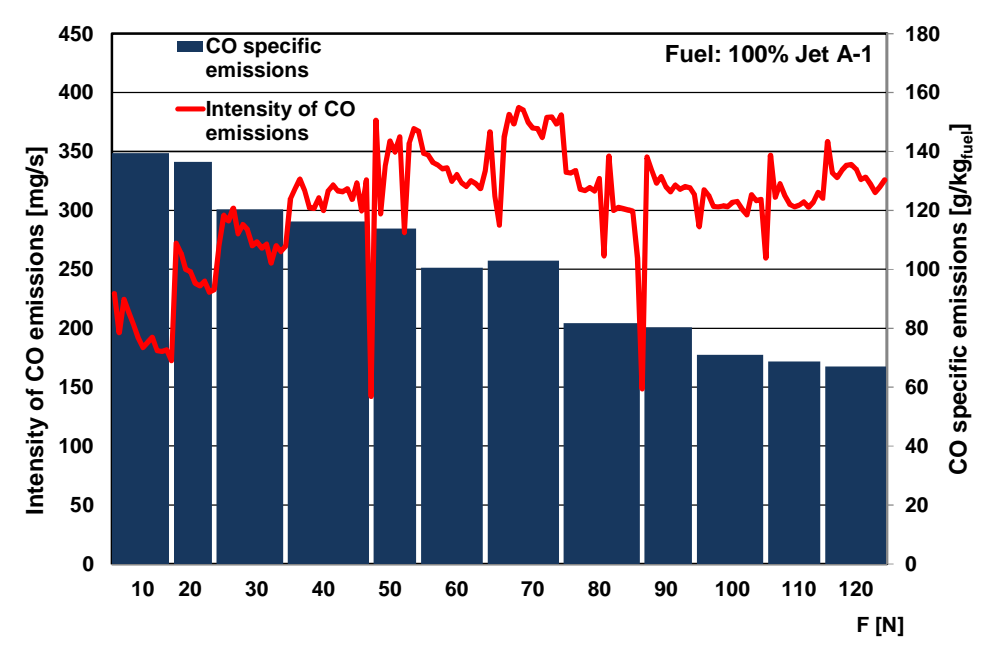

Fig. 11. The intensity of carbon monoxide emissions and the specific emissions for the jet engine powered with Jet A-1 fuel

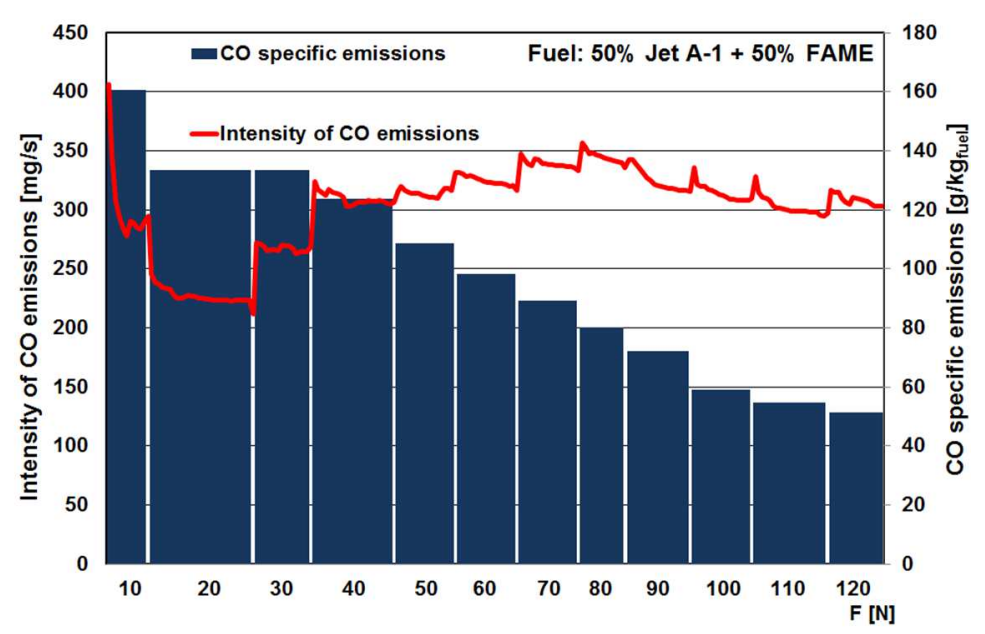

Fig. 12. The intensity of carbon monoxide emissions and the specific emissions for the jet engine powered with biofuel

In the case of gaseous emissions (hydrocarbons and carbon monoxide) significant changes resulting from the use of biofuel were found. In the case of hydrocarbons specific emissions a decrease was found particularly for large values of thrust. The use of biodiesel also resulted in a positive change for the measurement of carbon monoxide emissions. The use of biofuel allowed to reduce the emissions of carbon monoxide, particularly, for large values of thrust. 


\section{References}

[1] Chenga M., Chena H., Young L., Yangc H., Tsai Y., Wange L., Luf L., Cheng C.: Carbonaceous composition changes of heavy-duty diesel engine particles in relation to biodiesels, after treatments and engine loads, J. Hazardous Materials, 297 (2015) 234-240.

[2] Chuck C.J., Donnelly J.: The compatibility of potential bioderived fuels with Jet A-1 aviation Kerosene, Applied Energy, 118 (2014) 83-91.

[3] Górski K., Olszewski W., Lotko W.: Alcohols and ethers as fuels for diesel engines, Technical Trans., Mechanics, 105 (2008) 13-24.

[4] Hyslop N.P.: Impaired visibility: the air pollution people see, Atmospheric Environment 43, 182-195.

[5] ICAO: Convention on International Civil Aviation, 1944.

[6] ICAO: Environmental Protection (Annex 16) Aircraft Engine Emission, International Standards and Recommended Practices, 2008

[7] Johnson K., Durbin T., Cocker D., Miller J., Agama R., Moynahan N., Nayak G.: On-road evaluation of a PEMS for measuring gaseous in-use emissions from a heavy-duty diesel vehicle, SAE Technical Paper Series 2008-01-1300, 2010.

[8] Kivits R., Charles M.B., Ryan N.: A post-carbon aviation future: Airports and the transition to a cleaner aviation sector, Futures, 42 (2010) 199-211.

[9] Masiol M., Harrison R.M.: Aircraft engine exhaust emissions and other airport related contributions to ambient air pollution: A review, Atmospheric Environment, 95 (2014) 409-455.

[10]McPhail L.L., Babcock B.A.: Impact of US biofuel policy on US corn and gasoline price variability Lihong, Energy, 37 (2012) 505-513.

[11]Pielecha J., Jasiński R.: The assessment of the effect biofuel additive on jet engine exhaust emission, Logistyka, 4 (2015) 815-822.

[12]Ramanathan V., Feng Y.: Air pollution, greenhouse gases and climate change: Global and regional perspectives, Atmospheric Environment, 43 (2009) 37-50.

[13]Thompson W., Whistance J., Meyer S.: Effects of US biofuel policies on US and world petroleum product markets with consequences for greenhouse gas emissions, Energy Policy, 39 (2011) 5509-5518.

[14]Unal A., Hu Y., Chang M.E., Odman M.T., Russel A.G.: Airport related emissions and impacts on air quality: Application to the Atlanta International Airport, Atmospheric Environment, 39 (2005) 5787-5798.

[15]Winchester N., McConnachie D., Wollersheim C., Waitz I.A., Economic and emissions impacts of renewable fuel goals for aviation in the US, Transportation Research Part A, 58 (2013) 116-128.

[16]Zhang H., Mgara-Gomez K.T., Olson M.R., Okuda T., Walz K.A., Schauer J.J., Kleeman M.J.: Atmospheric impacts of black carbon emission reductions through the strategic use of biodiesel in California, Sci. Total Environment, 538 (2015) 412 422 . 


\section{EMISYJNOŚĆ TURBINOWEGO SILNIKA ZASILANEGO BIOPALIWEM}

\section{Streszczenie}

Transport lotniczy jest najmłodszą i najbardziej dynamicznie rozwijająca się gałęzią transportu. Wzrost zapotrzebowania na przewozy drogą lotniczą, zarówno pasażerskie i towarowe wynika głównie z krótkiego czasu transportu oraz bezpieczeństwa. Wzrost wolumenu transportowego związany jest ze wzrostem emisji związków szkodliwych spalin, co jest szczególnie istotne w kontekście emisji na terenie lotnisk oraz obszarach do nich przyległych. Głównym celem rozwoju konstrukcji silników lotniczych jest zmniejszenie zużycia paliwa i redukcja emisji związków toksycznych. Procedury certyfikacyjne dla silników odrzutowych marginalnie traktują zagadnienie cząstek stałych, które są powodem pogorszenia widzialności oraz chorób płuc i serca. Jednym z rozwiązań ograniczających wpływ transportu lotniczego na środowisko jest stosowanie paliw alternatywnych. W artykule przedstawiono wyniki pomiarów emisji związków szkodliwych silnia odrzutowego GTM-120. Badany silni zasilany był paliwem Jet A-1 oraz mieszanką nafty lotniczej z biopaliwem. Podczas badań zmierzono wartości stężenia tlenku węgla, węglowodorów oraz cząstek stałych. Na podstawie przeprowadzonych badań przedstawiono wpływ zastosowania biopaliwa na emisję związków szkodliwych.

Słowa kluczowe: biopaliwa, silnik odrzutowy, emisja, transport lotniczy

DOI: $10.7862 / \mathrm{rm} .2017 .07$

Otrzymano/received: 12.01 .2017

Zaakceptowano/accepted: 14.03.2017 